\title{
Management of fusarium yellows of gladiolus through cow urine and bioagent
}

\begin{abstract}
Gladiolus (Gladiolus grandiflorus) a member of family Iridaceae, is one of the important cut flower among ornamental crops grown in India. Fusarium wilt or yellows of gladiolus is a common problem which is caused by Fusarium oxysporum f. sp. gladioli. Experiments were carried out during 2009-10 and 2010-11 at Model Floriculture Centre, GBPUA\&T, Pantnagar to study the effect of bioagent and cow urine corm treatment on germination and wilt incidence of Gladiolus. The experiment was laid out with six treatments viz., Bavistine @ 0.2\%,Thiram@0.2\%,Copper Oxychloride@0.3\%,Trichoderma harzianum@0.10\%, Cow urine @ 0.50\% and Untreated Check. Findings of present investigation revealed that the corm treatment of Gladiolus with Trichoderma harzianum had maximum germination $(99.00 \%)$ as well as minimum incidence of wilt of Gladiolus to $(0.76 \%)$ followed by Cow urine with germination $(98.42 \%)$ and disease incidence of $(1.56 \%)$ respectively, which are statistically at par. Minimum germination $(32.12 \%)$ and maximum incidence $(88.45 \%)$ was observed in untreated check. This implies that corm treatment with bio agent and cow urine was good for enhancing the growth of plant hence more yield. The aim of the present study was to reduce the use of chemicals and increase use of biological sources to maintain the soil health, fertility and microbial activity.
\end{abstract}

Keywords: management, fusarium yellows, gladiolus, cow urine, bioagent
Volume 4 Issue I - 2020

\author{
Varsha Joshi,' Ranjan Srivastava, ${ }^{2}$ VS Pundhir' \\ 'Department of Plant Pathology, GB Pant University of \\ Agriculture \& Technology, India \\ 2Department of Horticulture, GB Pant University of Agriculture \\ \& Technology, India
}

Correspondence: Ranjan Srivastava, Department of Horticulture, GB Pant University of Agriculture \& Technology, Pantnagar-263145, India, Email ranjansrivastava25@gmail.com

Received: January 09, 2020 | Published: January 21, 2020

\section{Introduction}

Gladiolus (Gladiolus grandiflorus) belongs to the family Iridaceae and is an important cut flower or bulbous ornamental crop. It is cultivated throughout the world. It comprises over 180 species with more than 30,000 cultivars, out of which above 20 are grown for commercial flower production. ${ }^{1}$ The inflorescence of gladiolus known as spike comprises of funnel shaped individual flowers called floret. Gladiolus is commercially propagated through underground modified stem known as corms and cormels. It is known to have an excellent vase life and is considered as an economically important flower crop in India. Gladiolus is widely used in bouquet, flower arrangements, borders and bedding purposes. ${ }^{2}$ Gladiolus is affected by many diseases such as grey mould, leaf spots, storage rots, rust, and yellows. Among these, Fusarium yellows also known as Wilt, is one of the destructive disease wherever Gladiolus is grown. The disease was recorded for the first time on Gladiolus from California by Pryal. ${ }^{3}$ It further disseminated to United States ${ }^{4}$ and Britain. ${ }^{5}$ History, Economic Importance and symptoms are reported by Harrison. ${ }^{6}$ In India, the disease was first reported from Lucknow, Uttar Pradesh. ${ }^{7}$ Black brown lesions on corms and reduced florets are some of the symptoms of wilt disease of Gladiolus described by Singh et al. ${ }^{7}$ It is a major bottleneck in gladiolus cultivation causing $60-80 \%$ crop damage and huge economic loss to flower growers. ${ }^{8,9}$ The infected plants show symptoms of yellowing, bending of spikes, inability to bloom, production of small sized florets, drying and eventual death of plants. Fusarium corm rot can be observed both in field and during storage. ${ }^{10}$ The infected corms in storage develop brown to black lesions and eventually become mummified. Conventional management practices for Fusarium wilt disease include corm treatment with fungicides and soil fumigation. These measures are time consuming and labour intensive which also increase the cost of cultivation.

Chet and Elad ${ }^{11}$ found that coating of corm followed by broadcast application of $T$. harzianum significantly reduced the incidence of wilt disease caused by Rhizoctonia solani and Sclerotium rolfsii. Moon et al. ${ }^{12}$ studied the antagonism of $F$. oxysporum f.sp. fragariae and found that the disease incidence was reduced. $T$. harzianum and $T$. virides strongly promoted the growth of carnation cuttings and gave good control of wilt caused by F.oxysporum f.sp.dianthi.$^{13}$ T. virens inhibited the population of F.oxysporum f.sp. gladioli in soil. ${ }^{14}$ Cow urine has been proved to be inhibitory to the mycelial growth of Foxysporum f. sp. cucumerinum, F. solani f. sp. cucurbitae and S. sclerotium that cause disease in cucumber. ${ }^{15}$ Jabin ${ }^{16}$ reported cow urine has inhibitory effect on F. semitectum.

\section{Materials and methods}

The experiment was conducted at Model Floriculture Centre, GBPUA\&T, Pantnagar Uttarakhand (India) which was located at $29^{\circ}$ $\mathrm{N}$ latitude and $79.3^{\circ} \mathrm{E}$ longitude in the foot hills of the Himalaya at an altitude of $243.84 \mathrm{~m}$ above mean sea level. The gladiolus variety Pink Friendship, a commercial variety, was taken for the study to assess the response of cow unine and bioagent (Trichoderma harzianum) in the management of Fusarium wilt. The gladiolus corms of uniform size (10-12 grade) were taken from the Model Floriculture centre of the university which were kept in the cold storage during off season. The corms were treated with fungicides Bavistine @ 0.2\%, Thiram (a) 0.2\%, Copper Oxychloride @ 0.3\%,Bioagent (Trichoderma harzianum)@0.10\%, and Cow urine @ 0.50\% for 30 minutes and then air dried before planting. Allotted treatments were arranged in a randomized block design with three replications per treatment during cropping seasons 2009-10 and 2010-11. Each plot consisted of six rows. Before sowing the corms were dipped in a fungicidal solution for 30 minutes. Likewise corms were dipped in suspension having bioagent prepared in the Department of Plant Pathology of the university and fresh cow urine (collected from university dairy farm) for 30 minutes. Corms dipped in water for 30 minutes served as control for comparison. The crop was raised under uniform cultural practices throughout the growing season. The soil of the field was 
sandy loam having $\mathrm{pH} 6.68$ and electrical conductivity $0.43 \mathrm{dsm}^{-1}$. The N, P and K status of the soil was $232.47,17.96$ and $137.85 \mathrm{Kg} / \mathrm{ha}$, respectively. The corm sprouting per cent was recorded after 30 days and per cent disease incidence was recorded after 70 days of planting at weekly interval. Per cent disease incidence was calculated by the formula given below.

$$
\text { Disease Incidence }=\frac{\text { No. of diseased plants }}{\text { Total no. of plants examined }} \times 100
$$

\section{Results and discussion}

\section{Effect of corm treatment on sprouting of gladiolus}

The data presented in Table 1 \& Figure 1 indicated that corm treatment with bioagent (Trichoderma harzianum@0.10\%) and cow urine (@ 0.50\%)were effective in increasing the plant growth over control. During first year, the maximum sprouting was recorded in corms treated with bioagent followed by cow urine and Bavistine where the effect was statistically at par. A similar trend was recorded during second year of investigation. Among the mean, the maximum sprouting $(99.00 \%)$ was recorded in corms treated with Trichoderma harzianum which was statistically at par with cow urine (98.42\%), which were significantly higher over control. The sprouting in case of corms treated with Bavistine (94.77\%) followed by Thiram (92.89\%) and Copper Oxychloride (90.69 \%) respectively which were significantly different, while least sprouting was recorded in case of corms under control (32.12\%) which was significantly low. Trichoderma spp. are effective biocontrol agents for a number of soil-borne pathogens and are also known for their ability to promote plant growth. ${ }^{17}$ Trichoderma spp. change the plant rhizosphere soil environment and promote plant growth. ${ }^{18}$

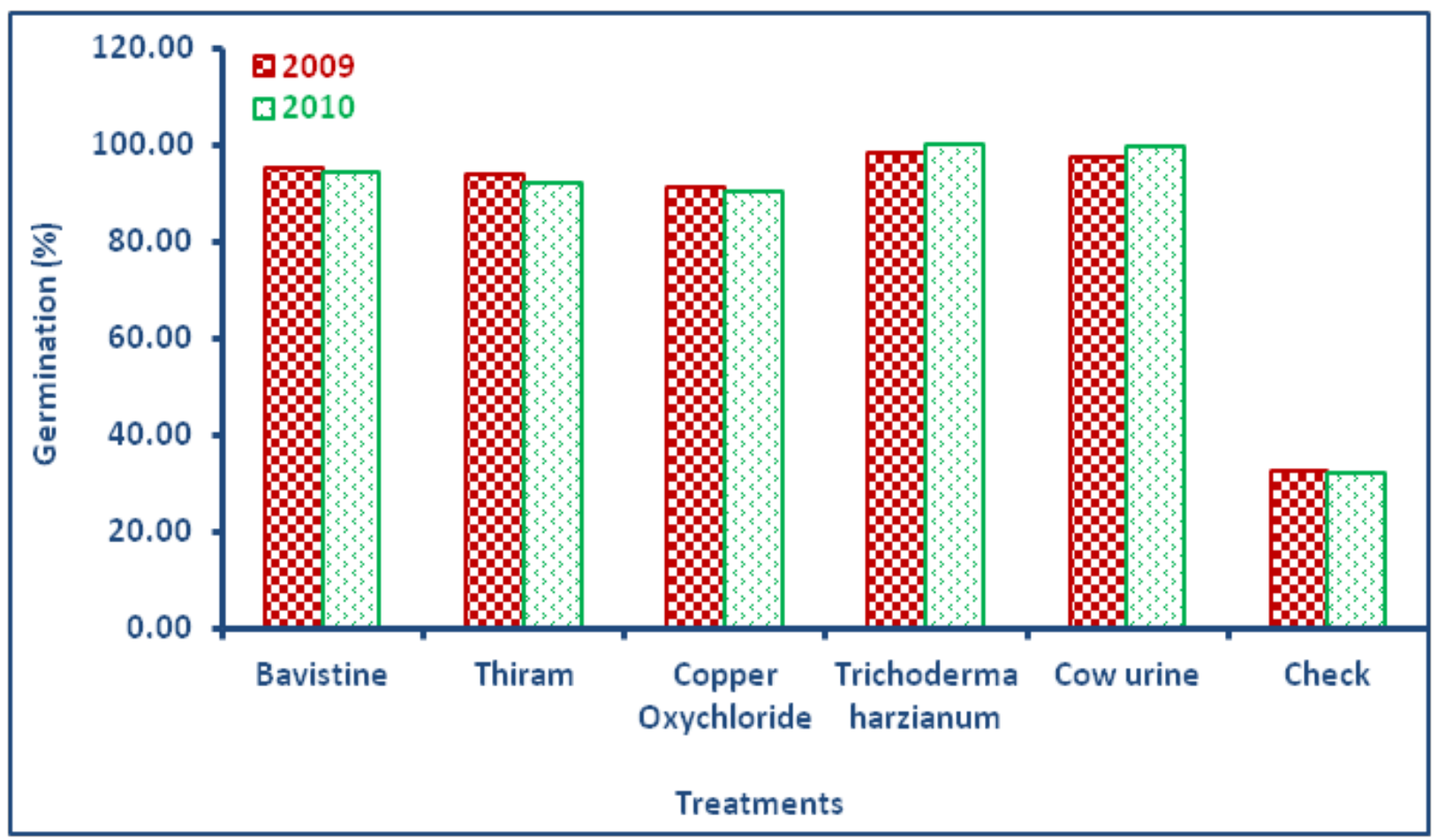

Figure I Effect of corm treatment on sprouting of gladiolus.

Table I Effect of corm treatment on sprouting of gladiolus

\begin{tabular}{llll}
\hline \multirow{2}{*}{ Treatments } & \multicolumn{3}{l}{ Germination Per cent (\%) } \\
\cline { 2 - 4 } & $\mathbf{2 0 0 9 - 1 0}$ & $\mathbf{2 0 1 0 - I I}$ & Mean \\
\hline Bavistine & 95.21 & 94.33 & 94.77 \\
Thiram & 93.78 & 92.00 & 92.89 \\
Copper Oxychloride & 91.24 & 90.14 & 90.69 \\
Trichoderma harzianm & 98.00 & 100.00 & 99.00 \\
Cow urine & 97.21 & 99.62 & 98.42 \\
Check & 32.24 & 32.00 & 32.12 \\
CD (0.05\%) & 2.97 & 5.70 & \\
CV & 2.49 & 4.79 & \\
& & & \\
& &
\end{tabular}




\section{Effect of corm treatment on percent disease incidence of gladiolus}

The corm treatment with Trichoderma harzianum gave better performance and reduced the incidence of wilt of Gladiolus to $(0.76 \%)$. I is evident from the data presented in Table 2 and Figure 2 that the percent disease incidence in gladiolus during both the years and also in mean of two years was lower in plants treated with bioagent and cow urine as compared to chemical treatments. In case of corms treated with Trichoderma harzianum and cow urine, the percent incidences of Fusarium yellows in pooled mean were $0.76 \%$ and $1.56 \%$, respectively. Percent disease incidence in case of corm treated with Copper Oxychloride (65.84\%), followed by Thiram (59.28\%) and Bavistine (51.29\%) which was significantly lower than untreated check (disease incidence of $88.45 \%$ ) (Table $2 \&$ Figure 2). These findings are similar to the findings of Angarita ${ }^{19}$ who reported the inhibitory activity of Trichoderma spp. against the different species of Fusarium. Basak and Lee ${ }^{15}$ reported that fresh cow urine and cow dung has positive response in suppression of mycelial growth of $F$. solani, F. oxysporum and S. sclerotiorum. Jabin ${ }^{16}$ reported inhibitory activity of cow urine against $F$. semitectum. Present study indicated the corm treatment with Trichoderma harzianum @ 0.10\% and Cow urine @ $0.50 \%$ was found most effective and superior among all the treatments and significant reduction in incidence of wilt of Gladiolus to $(0.76 \%)$ and $(1.56 \%)$ respectively. Jandiak et al. ${ }^{20}$ reported that all concentrations $(5,10$, and $15 \%)$ of cow urine were effective against the growth of the fungus which exhibited the significant inhibition in the growth of fungal plant pathogens. With increase in concentration of cow urine there was corresponding increase in the inhibition of vegetative growth of the fungal pathogens. The diameter of the fungal colonies in poisoned plates was lesser when compared to control plates and it indicates the antifungal effect of cow urine. The use of cow urine provides better alternative to synthetic chemicals which are expensive and pose potential danger to the farmers, marketers, consumers, and environment. The cow urine can be used as biopesticide.

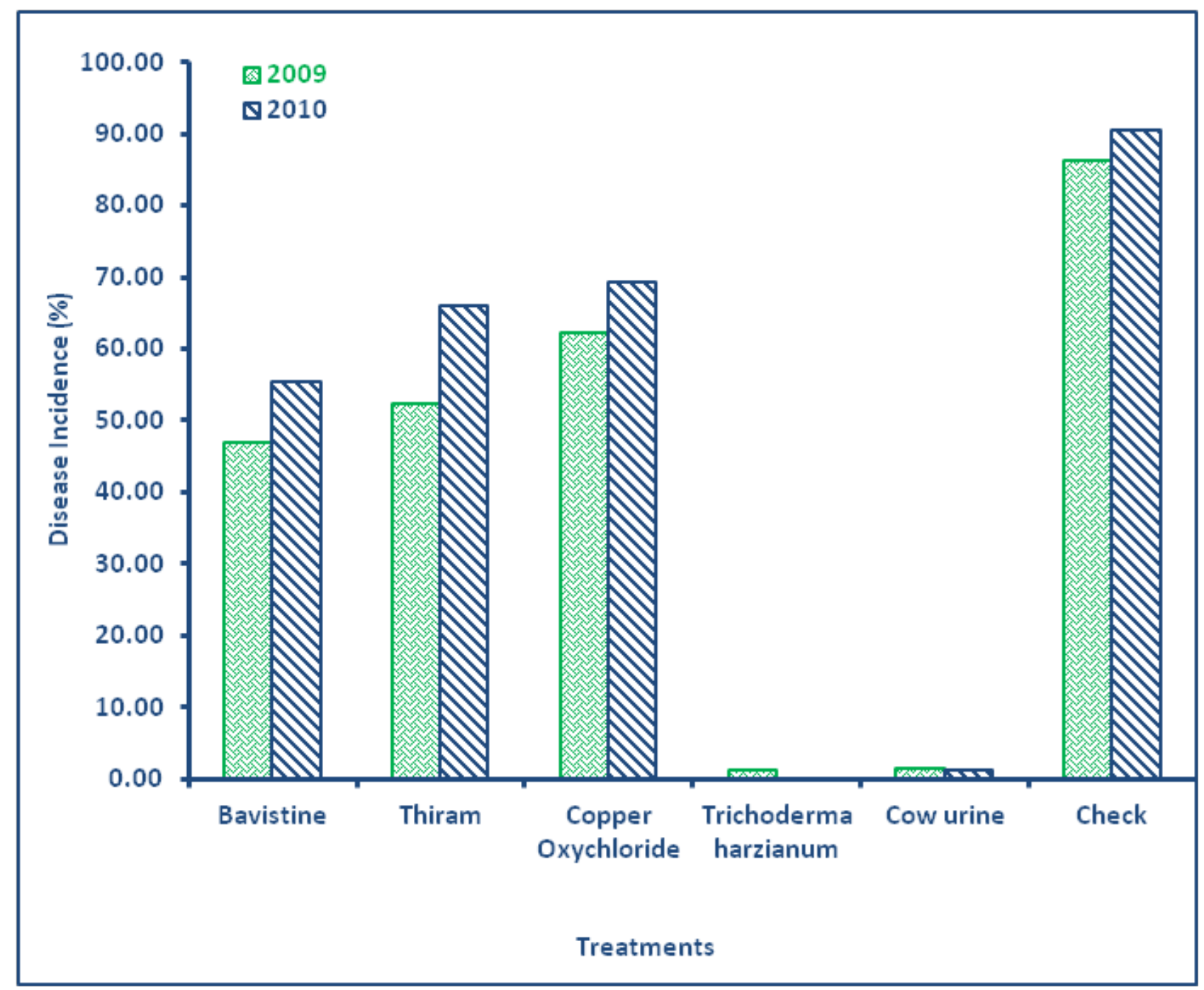

Figure 2 Effect of corm treatment on per cent disease incidence. 
Table 2 Effect of corm treatment on percent disease incidence

\begin{tabular}{|c|c|c|c|}
\hline \multirow[t]{2}{*}{ Treatments } & \multicolumn{3}{|c|}{ Per cent Disease Incidence (\%) ** } \\
\hline & 2009-10 & $2010-11$ & Mean \\
\hline \multirow[t]{2}{*}{ Bavistine } & 47.12 & 55.45 & 51.29 \\
\hline & $(43.35) *$ & -5.66 & \\
\hline \multirow[t]{2}{*}{ Thiram } & 52.36 & 66 & 59.18 \\
\hline & -46.35 & -5.98 & \\
\hline \multirow[t]{2}{*}{ Copper Oxychloride } & 63.33 & 69.33 & 65.84 \\
\hline & -52.14 & -7.08 & \\
\hline \multirow{2}{*}{$\begin{array}{l}\text { Trichoderma } \\
\text { harzianum }\end{array}$} & 1.33 & 0.18 & 0.76 \\
\hline & -6.63 & 0 & \\
\hline \multirow[t]{2}{*}{ Cow urine } & 1.66 & 1.44 & 1.56 \\
\hline & $-7.4 I$ & 0 & \\
\hline \multirow[t]{2}{*}{ Check } & 86.22 & 90.67 & 88.45 \\
\hline & -68.21 & -6.87 & \\
\hline CD (0.05\%) & 0.55 & 0.83 & \\
\hline CV & 0.82 & $\mathrm{I} .07$ & \\
\hline
\end{tabular}

*Figures in the parentheses are values after angular transformation

**mean of three replications

\section{Summary and conclusion}

Fusarium Yellows of Gladiolus one most destructive disease wherever Gladiolus is grown. This disease attracted the attention of the plant pathologists all over the world. Chemicals are known to have some negative effects on the environment and soil health. Being ecofriendly and easy availability to farmers, bio agent and cow urine are better options to use against wilt disease of Gladiolus.

\section{Acknowledgments}

The authors are grateful to the Model Floriculture Centre, GBPUA\&T, Pantnagar for providing the necessary facilities and encouragement.

\section{Conflicts of interests}

Authors declare no conflict of interest exists.

\section{References}

1. Misra RL, Singh B. Gladiolus. Commercial flowers. In: Bose TK, Yadav LP, editors. Calcutta: Naya Prokash; 1989. 874 p.

2. Dwivedi N, Deen B, Kumar A, et al. Standardization of vase solutions for maximum buds opening and longer vase-life of gladiolus flower cv. nova lux. Int J Curr Microbiol App Sci. 2018;7(3):3145-3150.

3. Pryal WA. Diseases of gladioli. Rural New Yorker. 1909;68:1009.
4. Massey LM. Fusarium rot of gladiolus corms. Phytopathology. 1926;16:509-523.

5. Moore WC. Diseases of bulbs. Bull Minist Agric. London; 1939. 176.

6. Harrison DE. Fusarium yellows and corm rot of Gladiolus. J Agric Vict. 1962;60:377-387.

7. Singh RN. A vascular disease of Gladiolus caused by Fusarium oxysporum f.sp. gladioli. Indian Phytopathology. 1969;22:402-403.

8. Lakshman DK, Pandey R, Kamo K, et al. Genetic transformation of Fusarium oxysporum f. sp. gladioliwith Agrobacterium to study pathogenesis in Gladiolus. European J Plant Path. 2012;133(3):729738.

9. Kakade DS, Jadhav SB, Katwate SM. Management of Fusarium wilt in Gladiolus. Int J Pure App Biosci. 2016;4(5):127-132.

10. Riaz Tariq, Khan Salik Nawaz, A Javaid, et al. Screening of Gladiolus germplasm for agronomic performance and resistance against corm rot disease. African J Biotechnology. 2010;9(40):6701-6707.

11. Chet I, Elad Y. Prevention of plant infection by biological means. France: Institute National De La Resaerche Agronomique Paris; 1982. p. 195-204.

12. Moon B, Chong H, Par K. Studies on antagonism of Trichoderma sp. to F.oxysporum f. sp. fragariae: Biological control of Fusarium wilt of strawberry by amycoparasite Trichoderma harzianum. Korean Journal of Plant Pathology. 1995;11:298-303.

13. Manka M, Fruzyneka JD, Pokojeka BA, et al. Promoting effect of Trichoderma on cutting growth in biocontrol of Fusarium carnation wilt. Flolia Horticulture. 1997;9:3-13.

14. Mishra PK, Mukhopadhyay AN, Singh US. Suppression of Fusarium oxysporum f.sp. gladioli populations in soil by application of Trichoderma virens and in vitro approaches for understanding biological control mechanism. Indian Phytopathology. 2004;57(1):44-47.

15. Basak AB, Lee MW. In vitro inhibitory activity of cow urine and cow dung of Fusarium solani f.sp. cucurbititae. Mycobiology. 2002;30(1):51-54.

16. Jabin M. In vitro inhibitory activity of cow urine, cow dung and medicinal plants extract against Fusarium senitectum. Berk and Rav. of Chilli. M.Sc. Thesis, Department of Botany, Chittagong University, Bangladesh; 2003. 107 p.

17. Harman GE, Howell CR, Viterbo A, et al. Trichoderma speciesopportunistic, avirulent plant symbionts. Nat Rev Microbiol. 2004;2:4356.

18. Halifu Saiyaremu, Xun Deng, Song Xiaoshuang, et al. Effects of two trichoderma strains on plant growth, rhizosphere soil nutrients and fungal community of pinus sylvestris var. mongolica annual seedlings. Forests. 2019; 10;758:1-17.

19. Angarita A. Effect of two Trichoderma spp. isolates on Fusarium oxysporum f. sp. dianthi in carnation. Acta Hort. 1997;482:133-157.

20. Jandaik Savita, Thakur Preeti, Vikas Kumar. Efficacy of cow urine as plant growth enhancer and antifungal agent. Advances in Agriculture. 2015. 